\title{
Molecular investigations of prevalence of human papillomavirus in Lithuania
}

\section{Daiva Ambrasiené $\dot{e}^{1 *}$,}

\author{
Algimantas Paulauskas ${ }^{1}$, \\ Neringa Girdauskaite் \\ Živilè Gudlevičiené $\dot{2}^{2}$ \\ ${ }^{1}$ Vytautas Magnus University, \\ K. Donelaičio St. 58, \\ LT-44037 Kaunas, Lithuania \\ ${ }^{2}$ Institute of Oncology, \\ Vilnius University, \\ Santariškiu St. 1, \\ LT-14028 Vilnius, Lithuania
}

HPV is one of the major risk factors of cervical cancer and precancerous changes. Infection with its oncogenic types determines a faster progress of pre-cancer changes. Women infected with oncogenic HPV types or multiple HPV infection must be under careful observation of a gynaecologist. The aim of this article is to identify infection of women who have various cytological changes in the cervix with the HPV and its genotypes by means of molecular methods.

A total of 99 women took part in the investigation (the experimental group is 33 women, the control group is 66). Flat epithelium cells from the cervix were taken to determine HPV, and DNA was isolated from all samples. The isolated DNA was studied to determine general HPV, and positive samples were genotyped (HV6/11, HPV16, HPV18, HPV31, HPV33, HPV45 and HPV59) by multiplex PCR. Having carried out HPV tests, twice as high incidence rate of infection with HPV in the experimental group than that in the control group was established (40 and $21 \%$, respectively). High cancer risk HPV genotypes were determined in $62 \%$ of women in the experimental group, whereas in the control group oncogenic HPVs of HPV16 and HPV31 genotypes were identified in $36 \%$ of women. Double HPV infection was diagnosed in 4 women in the experimental group, which can determine a faster progress of pre-cancer intra-epithelial lesions.

Key words: human papillomavirus, cervical intraepitelial lesions, HPV genotypes, PCR

\section{INTRODUCTION}

The human papillomavirus (HPV) is a group of viruses that have double helix ring DNA, which can infect the skin, the larynx, the oesophagus, and the genitals (Tewari et al., 2000). All in all, about 120 different HPV genotypes are known

\footnotetext{
* Corresponding author. E-mail: ambrasiene2007@yahoo.com
}

(Hausen, 2000). More than 40 HPV genotypes infect the sphere of the genitals. Clinical symptoms of HPV infection and the nature of the disease depend on the virus type (or genotype). According to the oncogenical nature, HPVs are divided into low (HVP 6, 11, 42, 43, 44) and high (HVP $16,18,31,33,35,39,45,50,51,53,55,56$, and others) cancer risk (oncogenic) types of viruses. High-risk HPV is a major and necessary factor in 
the development of HPV-related cervical cancer and cancer of other organs, whereas low-risk types encourage genital warts and different skin damages. Most often 16, 18, 31, 45 HPV types are identified in women who have cervical cancer (Milde-Langosch et al., 2000; Cogliano et al., 2005; Trottier, Franco, 2006). The investigations show that HPV infection increases the risk of contracting cervical cancer as many as several hundred times. According to the data of the investigation carried out in Lithuania (Gudleviciene et al., 2005), women infected with HPV run a 42 times higher risk of contracting cervical cancer than the women who are not infected with HPV. The risk increases even more if a woman is infected with high cancer risk types (HVP 16, $18,45)$. It is important to note that a part of diseases caused by HPV is related to low-risk types 6 and 11. These types cause malignant changes, however, they are associated not only with different changes of the uterus cervix or genital warts the incidence of which totals about a million new cases every year but also with changes in skin and papilomatose of the respiratory tract (Burd, 2003; Gunter, 2003; Lacey et al., 2006).

Cervical cancer is one of the most important problems determining human reproduction. Cancer of this type is second by prevalence (after breast cancer) among women worldwide (Parkin et al., 2005). HPV is one of the most common sexually transmitted infections, which is an important risk factor determining the development of cervical cancer. This relationship is understood as causative (Cogliano et al., 2005; Gunter, 2003). However, the majority of HPV infections are temporal for a human being and do not cause clinical consequences; $70 \%$ of new HPV infections disappear within one year, and approximately $90 \%$ pass off within two years because the immune system most often eliminates the virus from the organism. The process of cell transformation into cancerous cells is a longterm one. Cancer development might take decades or even longer in the people infected with HPV (Greenblatt, 2005; Sinal, Woods, 2005). The virus is identified in from 90 to $100 \%$ of women suffering from cervical cancer and only in $5-20 \%$ of healthy women. The investigations carried out in Lithuania showed that infection of patients suffering from cervical cancer with HPV accounts for $92.7 \%$, and that of patients without cancer pathology is $26.7 \%$ (Gudleviciene et al., 2005). Prevalence of the virus decreases with age. Sapy and others (2008) carried out investigations in Hungary and established that HPV of high oncological risk was identified in 1222 out of 3480 patients (35.1\%). The greatest number of women infected with the virus, i. e. $40 \%$ was in the age group over 25 years, in the group of $35-44$ year-old women this figure stood at $28 \%$, whereas only as little as $8 \%$ of patients was identified in the age group over 64 years. Most often HPV is found in women between the ages of 20 and 35 who lead an active sexual life and in those who change partners more often.

However, HPV is associated not only with 500,000 new cases of cervical cancer or 250,000 deaths from this disease but also with vaginal, anal and vulvar cancer, pre-cancer changes in vulva/vagina, genital warts. Many individuals often do not know that they are infected with HPV because infection during sexual intercourse spreads easily and unnoticeably (Daling et al., 2002; Moscicki, 2005; WHO, 2006; Anttila et al., 2009; Nicula et al., 2009).

The mortality rate from cervical cancer in Lithuania is one of the highest in Lithuania (Aleknavičienè et al., 2002; Smailyte et al., 2010). Every day from one to two women become ill with this pathology, every other patient dies from this disease. In 2005 alone, as many as 500 women (27.4/100 thousand) became ill in the country, 236 (13.0/100 thousand) women died. An increase in the mortality rate of young women (15-34 years old) has been observed (Aleknavičienè et al., 2002; Smailyte et al., 2010). The lowest incidence and mortality indicators are in Finland ( 4.3 cases $/ 100$ thousand women). This disease is the least prevalent in Serbia and Montenegro (27.4 cases/100 thousand women). Approximately 9.4/100 thousand women are diagnosed to be ill with cancer of that localisation in the Netherlands. The mortality frequency is 3 out of 100 thousand patients (Baseman, Koutsky, 2005). The neighbouring countries such as Poland and Latvia are also noted for high 
prevalence of cervical cancer. Every year 2278 (the mortality rate is $7.8 / 100$ thousand) women die in Poland, in Latvia this figure stands at 165 women (7.4/100 thousand) (Castellsague et al., 2007).

The first investigations into HPV carried out in Lithuania showed that HPV infection was widely spread among the women suffering from cervical cancer (92.7\%) (Gudleviciene et al., 2005). Our earlier population investigations, having assessed 4322 healthy individuals (males and females), showed that as much as $40 \%$ of people are carriers of the virus (Ambrasiene, Popendikyte, 2008), and higher risk genetypes were discovered in $51 \%$ of the individuals infected with HPV (Popendikyte et al., 2008). The present investigation is aimed at assessing prevalence of HPV infection among the women under investigation (women were diagnosed to be suffering from different kinds of pathology at a medical treatment institution) and women of the control group (carriers) by means of molecular methods and at assessing the prevalence of the most frequent high-risk genotypes.

\section{MATERIALS AND METHODS}

The investigation to determine HPV and identify separate HPV types has been carried out at the Faculty of Natural Sciences of Vytautas Magnus University, the Department of Biology, at the Laboratory of Molecular Ecology.

A total of 99 women took part in the investigation. The experimental group consisted of 33 women between the ages of 30 and 60 who appealed to the Institute of Oncology of Vilnius University about certain pathology of the uterus cervix. During a cytological investigation carried out at the National Pathology Centre the following flat cellular intra-epithelial lesions were determined: atypical squamous cells of undetermined significance (ASCUS) were identified in 15 women, two atypical squamous cells of undetermined significance, possible considerable atypical squamous cell intra-epithelial lesions (ASC-H), 9 insignificant low-grade squamous intraepithelial lesions (LSIL), four high grade cervical squamous intraepithelial lesions (HSIL), the degree of lesions was not made more exact (dysplasia) in 3 women. The control group consisted of 66 women between the ages of 16 and 55 whose samples were obtained from the private laboratory.

Samples to detect HPV and its types were taken with a sterile brush swab from the cervix and transferred to a $1.5 \mathrm{ml}$ vial containing $0.5 \mathrm{ml}$ of saline. The Wallach Papette broom-type device and a portable set of combined liquid media were used: a labelled Papspin vessel containing Papspin fixative (Thermo Shandon, Pittsburgh, Pennsylvania, USA). Prior to the beginning of the investigation the samples were stored at $+2^{\circ}-+8^{\circ} \mathrm{C}$ temperature. Later the samples contained in $1.5 \mathrm{ml}$ vials were delivered to the Laboratory of Molecular Ecology of Vytautas Magnus University.

The first stage of the investigation into HPV infection consists in DNA purification from the biological sample under investigation. To prepare DNA preparations the SORPOclean ${ }^{\mathrm{TM}}$ Genomic DNA Extraction Module (UAB SOR$\mathrm{PO}$, Lithuania) reagent kit with special microcolumns was used according to the manufacturer's recommendations.

The quality and quantity of purified DNA preparations (suitability for PCR) were assessed according to the control reaction of PCR human $\beta$-globino gene fragment using specific primers. Every PCR series was performed using the positive and negative control. Specially constructed plasmidic DNA with specific DNA fragments for the virus or its genotypes (Fermentas UAB, Lithuania) were used. DNA-free samples (an adequate amount of deionised water was poured into the reaction mixture instead of DNA) were used for the negative control.

To detect DNA of general HPV infection by means of PCR methods the reaction mixture containing 18 specific primers for different HPV genotypes was used (Gravitt et al., 2000; Sotlar et al., 2004). Thereby this reaction general HPV infection by the amplified fragment of 450 nucleotide couples is determined. For general HPV detection DNA was amplified by using a kit of SORPOline ${ }^{\text {Tx }}$ HPV (SORPO, Vilnius) reagents and methods. HPV infection is detected if a patient is infected with high and 
low risk virus types. A general PCR study includes the following high-risk HPV types: 16, 18, $31,33,35,39,51,52,56,58,59,68,73,82$, and the following low-risk HPV types: $6,11,40,42$, $45,53,54,55,61,62,64,66,67,70,71,72$, IS39, CP8304, CP6108, MM4, MM7, MM8 and others (Ambrasiene, Popendikyte, 2008).

Positive samples according to HPV infection were additionally analysed seeking to detect high and low risk HPV types using SORPOline ${ }^{\mathrm{Tm}}$ HPV genotyping reagent kits and methods. HPV genotypes were identified by means of multiplex PCR. Three reactions with specific primers were used: PCR HPV16 and HPV18 genotypes (457 and $322 \mathrm{np}$ PCR products, respectively) were identified by means of the first multiplex, HPV31, HPV33, HPV59 genotypes (263, 398 and $215 \mathrm{np}$ PCR products, respectively) were identified by means of the second multiplex PCR and the third multiplex PCR detected HPV45 and HPV6/11 genotypes (151 and 334 np PCR products, respectively).

The amplified PCR products were fractioned and analysed by means of electrophoresis in $1.5 \%$ agarosis gel stained by ethidium bromide. $15 \mu \mathrm{l}$ of the amplified product was taken for the test. After electrophoresis, products stained with ethidium bromide were analysed in a UV transilluminator.

\section{RESULTS AND DISCUSSION}

The data on infecting women with HPV and HPV genotypes obtained during the investigation in the experimental and control groups are presented in Table 1. A general human papillomavirus was detected in $40 \%$ of women (13) in the experimental group, whereas in the control group this figure stood at $21 \%$ of women (14). Almost twice as many HPV cases were recorded in the experimental group as compared with those in the control group.

Having carried out investigations into HPV types, various HPV genotypes were detected in 8 out of 13 (i. e. $62 \%$ ) women in the experimental group and in 5 out of $14(36 \%)$ women in the control group. Prevalence of HPV genotypes in both groups is shown in Table 1 .

Table 1. Women infected with HVP and HVP genotypes ( $\mathrm{n}$ is the number of samples studied)

\begin{tabular}{c|ccc|cc}
\hline $\begin{array}{c}\text { Experimental } \\
\text { group }\end{array}$ & \multicolumn{2}{|c|}{$\begin{array}{c}\text { Infection rate } \\
\text { with HPV n, \% }\end{array}$} & \multicolumn{2}{c}{$\begin{array}{c}\text { HPV geno- } \\
\text { types n, \% }\end{array}$} \\
\hline Control $(\mathrm{n}=66)$ & 14 & 21 & 36 & 36 \\
\hline Patients $(\mathrm{n}=33)$ & 3 & 40 & 62 & 62 \\
\hline
\end{tabular}

By means of the multiplex polymerase chain reaction (PCR) high-risk cancer HPV16 and HPV18typeswereidentified(Fig.1). Ofallgenital

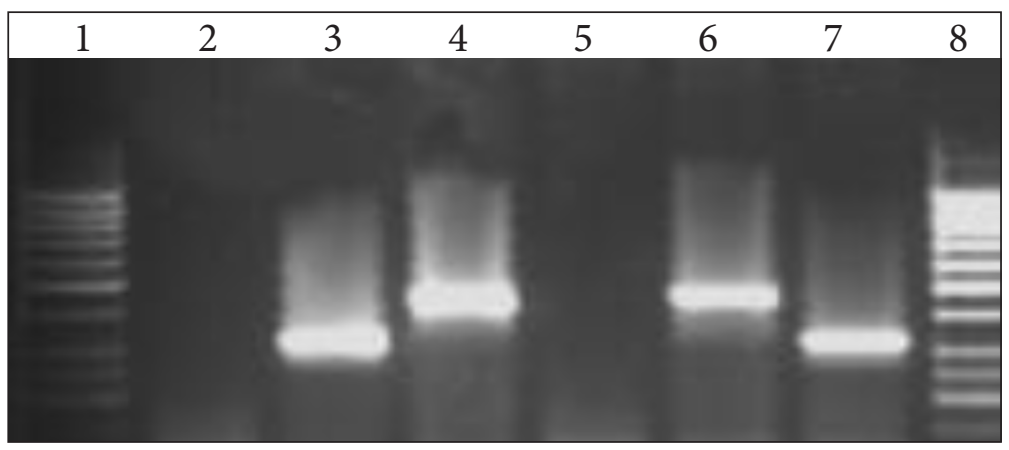

Fig. 1. Electrophoregram of identifying HPV16 and HPV18 genotypes by the multiplex PCR method. Paths 1 and 8 are the $50 \mathrm{bp}$ molecular mark (Fermentas UAB); path 2 is the negative control; path 5 is a negative sample of HPV genotyping; path 4 is the sample under study with HPV 16 genotype infection (specific 457 bp PCR product); path 3 is the sample under study infected with HPV 18 (specific 322 bp DNA fragment); path 6 is the positive HPV16 control (457 bp), path 7 is the positive HPV18 control (322 bp) 
HPV types HPV16 and HPV18 are most often found in cervical squamous cell carcinomas. In the genotyped group of 13 patients, HPV 16 and HPV18 genotypes were identified in more than a half of individuals under study - in 8 individuals (62\%) (40 and $15 \%$, respectively), and in the control group, only HPV16 type was identified in two women (14\%), that is, four times less as compared with the group of patients. The results of this study correspond with the earlier results of our studies in Lithuania and abroad. HPV16 and HPV18 account for 51.7\% (37.9 and $13.8 \%$, respectively) by Popendikyte et al. (2008), HPV 16 account for $29 \%$ and HPV 18 for $5 \%$ by Ambrasienè and Popendikyte (2008), and Grinsztejn et al. [2009] established that HPV16 and HPV18 genotypes, which are related to cervical cancer most, were detected in 23 and 13\% of samples, respectively. During the investigation Munoz (France) and others also established that HPV16 was most often detected among the infected women (54.6\%). Meantime HPV18 was detected in $11 \%$ of women in the group of patients only and in $7.3 \%$ of women in the control group (Munoz et al., 2003), (Fig. 4).

By means of another multiplex PCR it was determined whether HPV31, HPV33, HPV59 genotypes were present in the sample under study. These are high-risk genotypes detected in the samples of carcinomas and dysplasias of a different degree. However, HPV31 and HPV33 genotypes are referred to as high-risk viruses of an intermediary group by some authors because they are more often found in medium or distinct dysplasias than in carcinomas. The elecrophoregram of identifying HPV31, HPV33 and HPV59 genotypes by means of the multiplex PCR method is presented in Fig. 1. The HPV31 genotype was found in two women out of the 13 infected women in the group of patients (15\%) who also had the HPV16 type. HPV31 was detected in two patients (14\%) in the control group too. During the investigation HPV33 and HPV59 types were detected in none of the samples. Whereas the investigations carried out earlier in Lithuania during which prevalence of human papillomavirus and their types was studied established that the infection rate with HPV31 in the experimental group (patients suffering from cervical cancer) accounted for as little as $2.6 \%$, in the control group this figure stood at $0.2 \%$, and the infection rate with HPV33 accounted for $21 \%$ and $2 \%$, respectively (Gudlevičienè et al., 2005). In Popendikytës investigation the distribution of genotypes was as follows: HPV31 16\%, HPV33 11\%, HPV59 2.9\% (Popendikyte et al., 2008) and HPV31 11\%, HPV33 9\%, HPV59 6\% (Ambrasiene, Popendikyte, 2008) (Fig. 4). In our investigation (as in other investigations in Lithuania) the HPV18 type was not so common than the HPV31 type.

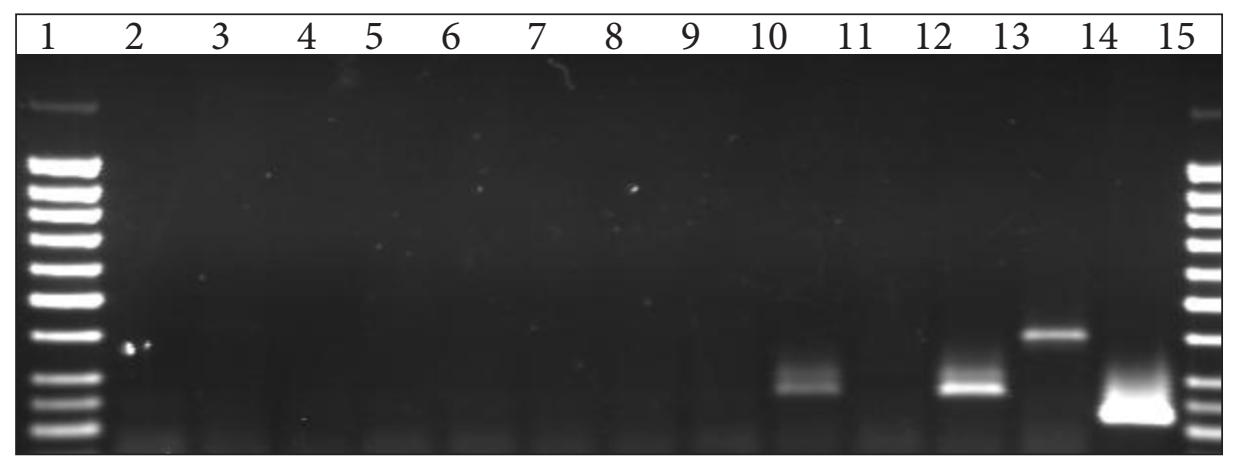

Fig. 2. The electrophoregram of identifying HPV31, HPV33 and HPV59 genotypes by means of the multiplex PCR method. Paths 1 and 15 are the 50 bp molecular mark (Fermentas UAB); path 2 is the negative control; paths 3, 4, 5, 6, 7, 8, 9 and 11 are negative samples of HPV genotyping; path 10 is the sample under study containing HPV31 genotype infection (specific 263 bp PCR product); path 12 is positive HPV31 control (263 bp); path 13 is the HPV33 control (398 bp); path 14 is the HPV59 control (215 bp) 
Figure 3 presents the results of the PCR reaction - identification of HPV45 and HPV6/11 genotypes. Low-risk HPV6/11 types are most often related to flat warts and weak dysplasias. This type was detected in one woman in the control group (7\%). It was not found in the experimental group. The HPV45 genotype is attributed to high-risk HPV and is detected in the samples of carcinomas and dysplasias of different degree. HPV45r was also detected in two women in the experimen- tal group (15\%) who were already infected with HPV16 or HPV18. It goes without saying that genotype co-infection makes clinics and prognosis of the patients more difficult. The investigations carried out by Gudlevičiene and co-authors showed that high-risk HPV45 was detected in only $1 \%$ of women (2) in the experimental and $0.2 \%$ (1) of women in the control group (Gudleviciene et al., 2005), HPV 45 in 7.5\%, HPV45 in 2\%, and HPV6/11 in 7\% (Popendikytè et al., 2008) (Fig. 4).

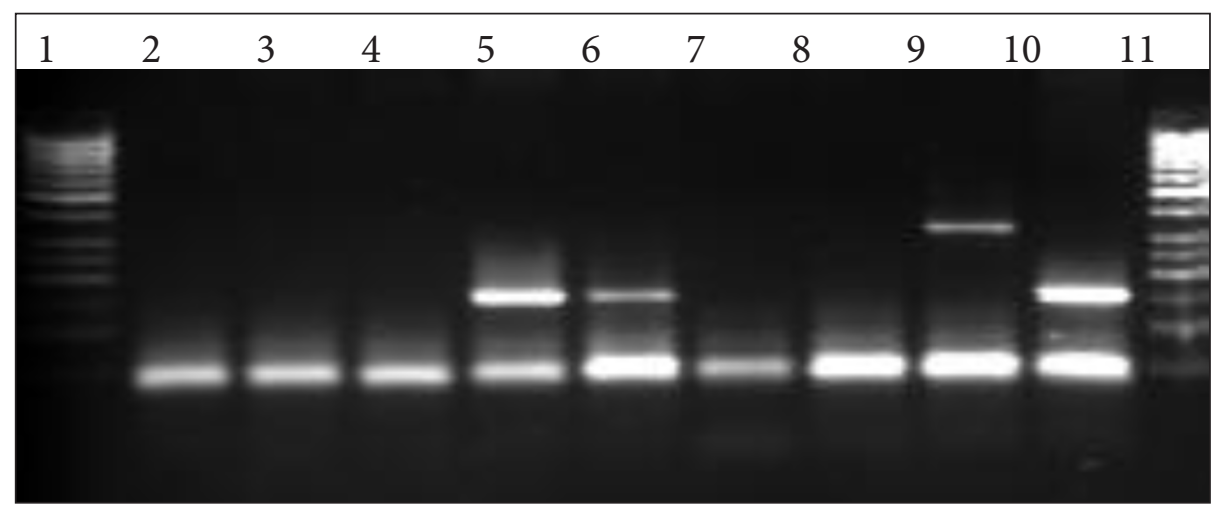

Fig. 3. The electrophoregram of identifying HPV11 and HPV49 genotypes by means of the multiplex PCR method. Paths 1 and 11 are the 50 bp molecular mark (Fermentas $\mathrm{UAB}$ ); path 2 is the negative control; paths $3,4,7,8$, are negative samples of HPV genotyping; paths 5 and 6 are the positive HPV45 control (151 bp); path 9 is the HPV6/11 control (334 bp); path 10 is the HPV45 control (151 bp)



Fig. 4. Prevalence of HPV genotypes (\%) identified during the investigation and comparison with that in the European countries ( ${ }^{*}$ no data found). Lithuania-1 - results obtained by Popendikytė et al. (2008), Lithuania-2 - by Ambrasienè, Popendikytè (2008), Latvia - by Silins et al., Slovenia - by Jancar et al. (2009), Poland - by Bardin et al., (2008), Italy - by Capra et al. (2008) and Belgium - by Arbyn et al. (2009) 
Constant oncogenic HPV types help change the cells and cause changes due to which cervical cancer might develop. High-risk genotypes have been identified in 8 out of 13 patients $(62 \%)$ in the experimental group (Table 1). As many as two high-risk genotypes have been identified in four women in this group (HPV16 and HPV 31 in two women and HPV16 and HPV45, HPV18 and HPV45 in others), and one high-risk genotype was identified in four women. These types are attributed to high risk HPV, which are related to skin or epithelium dysplasia if a great degree or the development of HPV-related cervical cancer or cancer of other organs. Oncogenic genotypes HPV16, HPV31 and low-risk HPV6/11 have been identified in five out of 14 (36\%) women in the control group. $29 \%(\mathrm{n}=4)$ of high-risk HPV16 14\%, HPV31 $14 \%$, and one low-risk genotype HPV6/11 7\% have been determined. More oncogentic types of HPV (HPV16, HPV18, HPV31, HPV45) were identified in the experimental group than in the control group (HPV16, HPV31 and HPV6/11).

\section{Summing-up}

The investigation carried out showed that general human papillomavirus was identified in 13 out of 33 (40\%) women in the experimental group, and in 14 out of 66 (21\%) women in the control group. More than $30 \%$ of the women that were studied and had general HPV were infected with the HPV16 type. As compared with other European countries, according to HPV prevalence, neighbouring Latvia $(60.6 \%)$ and Slovenia (64.9\%) are in the lead (Silins et al., 2004; Jancar et al., 2009). Results obtained in Poland (33\%) are similar to the results obtained during this investigation (Bardin et al., 2008). The HPV18 type has been identified in women $(7 \%)$ in the experimental group, whereas in the control group this type has not been detected. Prevalence of the HPV18 genotype is similar in all the countries, from 6.4\% (Poland) to $12.2 \%$ (Slovenia) (Bardin et al., 2008; Jancar et al., 2009). The greatest prevalence of other high-risk genotypes (HPV31 and 45), however, has been recorded in our country, 15 and 7\%, respectively, whereas in Slovenia this figure stands at 3.6 and $4.1 \%$ (Jancar et al., 2009). HPV 33 and HPV59 types have not been detected in either sample. Contrary to the control group, as many as two HPV genotypes have been identified in the women in the experimental group who were infected with HPV, which makes clinics more difficult and increases the risk of contracting cervical cancer. Also, the women who are infected with one of HPV types (for example, HPV31 or HPV45), most often also have the HPV16 type. Only one of all the studied women was infected with the HPV6/11 type, which accounts for $4 \%$ of low-risk HPV cases.

The investigations carried out into HPV prevalence show that apart from the most aggressive 16 and $18 \mathrm{HPV}$ types, other high-risk types have been identified not only in the experimental group but also among the virus carriers. Hence, identification of HPV virus and its types is of great importance not only to early diagnostics and prevention of oncological diseases but also to studies of clinical symptoms of HPV infection, epidemiology, and the evaluation of effectiveness of HPV vaccines.

\section{CONCLUSIONS}

1. It has been established during the investigation that $40 \%$ of women in the experimental group and $21 \%$ of women in the control group were infected with HPV.

2. It has been established that the HPV16 type prevails among the women infected with HPV. The HPV31 genotype is second by prevalence in both groups, which has been identified in $15 \%$ of women.

Received 2 June 2015

Accepted 2 September 2015

\section{References}

1. Aleknavičienė B, Smailyte G, Elaawar B, Kurtinaitis J. Cervical cancer: recent trends of in- 
cidence and mortality in Lithuania. Medicina. 2002; 38: 223-30. Lithuanian.

2. Ambrasiene D, Popendikyte V, Investigation of human papillomavirus. Lab Med. 2008; 38: 78-88. Lithuanian.

3. Anttila A, von Karsa L, Aasmaa A, Fender M, Patnick J, Rebolj M, et al. Cervical cancer screening policies and coverage in Europe. Eur J Cancer. 2009; 45: 2649-58.

4. Arbyn M, Benoy I, Simoens C, Bogers J, Beutels P, Depuydt C. Prevaccination distribution of human papillomavirus types in women attending at cervical cancer screening in Belgium. Cancer Epidemiol Biomark Prev. 2009; 18: $321-30$.

5. Bardin A, Vaccarella S, Clifford GM, Lissowska J, Rekosz M, Bobkiewicz P, et al. Human papillomavirus infection in women with and without cervical cancer in Warsaw, Poland. Eur J Cancer. 2008; 44: 557-64.

6. Baseman JG, Koutsky LA. The epidemiology of human papillomavirus infections. J Clin Virol. 2005; 32: S16-24.

7. Burd EM. Human papillomavirus and cervical cancer. Clin Microbiol Rev. 2003; 16: 1-17.

8. Capra G, Giovannelli L, Bellavia C, Colomba Migliore M, Caleca MP, Perino A, et al. HPV genotype prevalence in cytologically abnormal cervical samples from women living in south Italy. Virus Res. 2008; 133: 195-200.

9. Castellsague X, de Sanjosé T, Aguado KS, Louie L, Bruni J, Muñoz M, et al. HPV and Cervical Cancer in the World 2007 Report. Vaccine. 2007; 25 Suppl 3: C1-26.

10. Cogliano V, Baan R, Straif K, Grosse Y, Secre$\tan$ B, El Ghissassi F, et al. Carcinogenicity of human papillomaviruses. Lancet Oncol. 2005; 6: 204

11. Daling JR, Madeleine MM, Schwartz SM, Shera KA, Cartier JJ, McKnight B, et al. A population-based study of squamous cell vaginal cancer: HPV and cofactors. Gynecol Oncol. 2002; 84: 263-70.

12. Gravitt PE, Peyton CL, Alessi TQ, Wheeler CM, Coutlee F, Hilddesheim A, et al. Im- proved amplification of genital human papillomaviruses. J Clin Microbiol. 2000; 38: 357-61.

13. Greenblatt RJ. Human papillomaviruses: diseases, diagnosis, and a possible vaccine. Clin Microbiol. 2005; 27: 139-45.

14. Grinsztejn B, Veloso VG, Levi JE, Velasque L, Luz Mendes P, Friedman RK, et al. Factors associated with increased prevalence of human papillomavirus infection in a cohort of HIVinfected Brazilian women. Int J Infect Dis. 2009; 13: 72-80.

15. Gudleviciene Z, Didziapetriene J, Suziedelis K, Lapkauskaite L. Investigation of human papillomavirus, its types and variants. Medicina. 2005; 41: 910-5. Lithuanian.

16. Gunter J. Genital and perianal warts: new treatment opportunities for human papillomavirus infection. Am J Obstet Gynecol. 2003; 189: S3-1.

17. Hausen H. Papillomaviruses causing cancer: evasion from host-cell control in early events in carcinogenesis. J Natl Cancer Inst. 2000; 92 : 690-8.

18. Jancar N, Kochan BJ, Poljak M, Lunar MM, Vrtacnik Bokal E. Distribution of human papillomavirus genotypes in women with cervical cancer in Slovenia. Eur J Obstet Gyn R B. 2009; 145: 184-8.

19. Lacey CJ, Lowndes CM, Shah KV. Chapter 4: Burden and management of noncancerous HPV-related conditions: HPV-6/11 disease. Vaccine. 2006; 24 Suppl 3: S35-41.

20. Milde-Langosch K, Riethdorf S, Loning T. Association of human papillomavirus infection with carcinoma of the cervix uteri and its precursor lesions: theorethical and practical implications. Virchows Arc. 2000; 437: 227-33.

21. Moscicki AB. Impact of HPV infection in adolescent populations. J Adolesc Health. 2005; 37: S3-9.

22. Munoz N, Bosch FX, de Sanjose S, Herrero R, Castellsague X, Shah KV, et al. Epidemiologic classification of human papillomavirus types associated with cervical cancer. $\mathrm{N}$ Engl J Med. 2003; 348: 518-27. 
23. Nicula FA, Anttila A, Neamtiu L, Zakelj MP, Tachezy R, Chil A, et al. Challenges in starting organised screening programmes for cervical cancer in the new member states of the European Unijon. Eur J Cancer. 2009; 45: 2679-84.

24. Parkin DM, Bray F, Ferlay J, Pisani P. Global cancer statistics. CA Cancer J Clin. 2005; 55: 74-108.

25. Popendikyte V, Gulbinovič I, Paulauskiene V, Paulauskas D. Detection and typing of high risk papillomavirus by Multiplex PCR. Lietuvos akušerija ir ginekologija. 2008; 4: 348-52. Lithuanian.

26. Sapy T, Poka R, Szarka K, Konya J, Huga S, Hernadi $Z$. Age-specific prevalence of high-risk human papillomavirus infection in a Hungarian female population with positive cytology. Eur J Obstet Gyn R B. 2008; 138: 194-8.

27. Silins I, Wang X, Tadesse A, Jansen KU, Schiller JT, Avall-Lundqvist E., et al. A populationbased study of cervical carcinoma and HPV infection in Latvia. Gynecol Oncol. 2004; 93: 484-92.

28. Sinal SH, Woods CR. Human papillomavirus infections of the genital and respiratory tracts in young children. Semin Pediat Infect Dis. 2005; 16: 306-16.

29. Smailytè G, Rimiene J, Gudlevičiene Z, Aleknevičiene B. Influence of the cervical cancer screening programme on cervical cancer incidence in Lithuania. Theory and Practice in Medicine. 2010; 16: 159-64. Lithuanian.

30. Sotlar K, Diemer D, Dethleffs A, Hack Y, Stubner A, Vollmer N, et al. Detection and typing of human papillomavirus by e6 nested multiplex PCR. J Clin Microbiol. 2004; 42: 3176-84.

31. Tewari KS, Taylor JA, Liao SY, DiSaia PJ, Burger RA, Monk BJ, et al. Development and assessment of a general theory of cervic carcinogenesis utilizing a severe combined immunodeficiency murine-human xenograft model. Gynecol Oncol. 2000; 77: 137-48.

32. Trottier H, Franco EL. The epidemiology of genital human papillomavirus infection. Vaccine. 2006; 24: S1-15.
33. World Health Organization [Internet]. Geneva, Switzerland: World Health Organization; 2006. Initiative for vaccine research. Human papillomavirus. Available from: http://www. who.int/vaccine_research/diseases/viral_cancers/en/index $3 . h t m l$

\section{Daiva Ambrasienè, Algimantas Paulauskas, Neringa Girdauskaitė, Živilè Gudlevičienė}

\section{ŽMOGAUS PAPILOMOS VIRUSO MOLEKULINIAI TYRIMAI LIETUVOJE}

\section{Santrauka}

Žmogaus papilomos virusas - vienas pagrindinių gimdos kaklelio vèžio ir ikivèžinių pokyčių rizikos veiksnių. Infekuotumas onkogeniniais jo tipais lemia greitesnę pokyčių progresiją iki vèžio. Moterys, infekuotos onkogeniniais ŽPV tipais ar daugine ŽPV infekcija, turi būti atidžiau stebimos ginekologo. Šio straipsnio tikslas - nustatyti moteru su ivairiais gimdos kaklelio citologiniais pokyčiais infekuotumą ŽPV bei jo genotipais naudojant molekulinius metodus.

I tyrimą ittrauktos 99 moterys. Tiriamojoje grupẻje 33 moterims nustatyti ịvairaus laipsnio intraepiteliniai pokyčiai. 66 moterys, kurioms nenustatyta citologinių pokyčių, sudare kontrolinę grupę. ŽPV ištyrimui buvo imamos plokščiojo epitelio ląstelès iš gimdos kaklelio, DNR išskirta iš visų mėginių. Išskirtoji DNR buvo tirta siekiant nustatyti bendrą ŽPV, o teigiami pavyzdžiai genotipuoti (ŽPV6/11, ŽPV16, ŽPV18, ŽPV31, ŽPV33, ŽPV45 ir ŽPV59) naudojant daugines PGR su specifiniais pradmenimis. ŽPV tyrimais tiriamojoje grupeje nustatytas du kartus didesnis infekuotumas ŽPV negu kontrolinèje (atitinkamai 40 ir $21 \%$ ). $62 \%$ tiriamosios grupès moterų nustatyti didelès věžio rizikos ŽPV genotipai - ŽPV16, ŽPV18, ŽPV31 bei ŽPV45, kontrolinèje grupeje $36 \%$ moterų identifikuoti tik ŽPV16 ir ŽPV31 onkogeniniai ŽPV. Keturioms tiriamosios grupès moterims nustatyta dviguba ŽPV infekcija, kuri gali lemti greitesnę intraepitelinių pokyčių progresiją iki vèžio.

Raktažodžiai: žmogaus papilomos virusas, intraepiteliniai pokyčiai, ŽPV genotipai, PGR 